\title{
Use of Cross-Flow Membrane Filtration in a Recirculating Hydroponic System to Suppress Root Disease in Pepper Caused by Pythium myriotylum
}

\author{
Andrew C. Schuerger and William Hammer
}

First author: Department of Plant Pathology, University of Florida, Space Life Sciences Lab, Bldg. M6-1025, Kennedy Space Center, FL 32899; and second author: The Land, Epcot, Lake Buena Vista, FL 32830.

Accepted for publication 5 January 2009.

\begin{abstract}
Schuerger, A. C., and Hammer, W. 2009. Use of cross-flow membrane filtration in a recirculating hydroponic system to suppress root disease in pepper caused by Pythium myriotylum. Phytopathology 99:597-607.

Zoosporic pathogens in the genera Pythium and Phytophthora cause extensive root disease epiphytotics in recirculating hydroponic vegetableproduction greenhouses. Zoospore cysts of Pythium myriotylum Drechsler were used to evaluate the effectiveness of cross-flow membrane filters to control pythiaceous pathogens in recirculating hydroponic systems. Four membrane filter brands (Honeycomb, Polypure, Polymate, and Absolife) were tested alone or in combination to determine which filters would effectively remove infective propagules of $P$. myriotylum from solutions and reduce disease incidence and severity. Zoospore cysts of $P$. myriotylum generally measured 8 to $10 \mu \mathrm{m}$, and it was hypothesized that filters with pore-sizes $<5 \mu \mathrm{m}$ would be effective at removing $100 \%$ of the infective propagules and protect pepper plants from root infection.

Single-filter assays with Honeycomb and Polypure brands removed 85 to $95 \%$ of zoospore cysts when pore sizes were rated at $1,5,10,20$, or $30 \mu \mathrm{m}$. Single-filter assays of Polymate and Absolife brands were more effective, exhibiting apparently $100 \%$ removal of zoospore cysts from nutrient solutions on filters rated at 1 to $10 \mu \mathrm{m}$. However, plant bioassays with Honeycomb and Polymate single filters failed to give long-term protection of pepper plants. Double-filter assays with 1 - and $0.5-\mu \mathrm{m}$ Polymate filters significantly increased the protection of pepper plants grown in nutrient film technique systems but, eventually, root disease and plant wilt could be observed. Insect transmissions by shore flies were not factors in disease development. Scanning electron microscopy images of zoospore cysts entrapped on Polymate filters revealed zoospore cysts that were either fully encysted, partially encysted, or of unusually small size ( $3 \mu \mathrm{m}$ in diameter). It was concluded that either the atypically small or pliable pleomorphic zoospore cysts were able to penetrate filter membranes that theoretically should have captured them.
\end{abstract}

Hydroponic plant production methods have increased in complexity and diversity since the mid-1950s, when the technology was first used widely in commercial greenhouses. Modern systems include such techniques as ebb and flow, nutrient film technique (NFT), aeroponic, flooded raceways, rockwool, and sand culture. Various crops have been produced using hydroponic technologies but usually only high cash crops such as tomato, cucumber, lettuce, or pepper are produced.

Root-infecting pathogens have been reported in hydroponic systems wherever these technologies have been utilized. Species of Pythium and Phytophthora are the most frequently reported root pathogens in recirculating hydroponic systems $(1,9,10,12$, 17,29,34). The biology of zoosporic pathogens makes them ideally suited for the development of rapid and severe epiphytotics, particularly in recirculating hydroponic systems. Motile zoospores of pythiaceous fungi attach to root tips and at the bases of root hairs. Plant ingress may occur within $15 \mathrm{~min}$ (12), followed by rapid development of the fungus within the root. Secondary inoculum can be produced within $24 \mathrm{~h}$; thus, incremental increases in the numbers of zoospores for dissemination in the nutrient solution can be exceedingly fast. Although severe root rots caused by pythiaceous pathogens have been reported $(1,12$, $34)$, some species of pythiaceous fungi can cause subclinical disease $(24,29)$.

Corresponding author: A. C. Schuerger; E-mail address: acschuerger@ifas.ufl.edu

doi:10.1094/PHYTO-99-5-0597

(c) 2009 The American Phytopathological Society
Diverse control options have been employed to reduce the severity of disease outbreaks or delay dispersal of pythiaceous pathogens in hydroponic systems $(8,23,30)$. The most common control methods include sanitation, fungicides, surfactants, oxidative biocides, ultraviolet irradiation, ozone, heat-sterilization, biological control, and filtration. Each control option has advantages and disadvantages and no single approach has proven effective for all root pathogens encountered in hydroponic systems. Filtration was selected for the current research effort based on its effectiveness in removing large quantities of propagules in hydroponic solutions and irrigation waters, and the lack of chemical alterations of nutrient solutions observed for other treatments such as the addition of chemical biocides, ultraviolet irradiation, or ozone.

Two filtration technologies have been used commercially in recirculating hydroponic systems to varying degrees of effectiveness. Slow sand filtration utilizes a series of graded gravels and sand particles to create a slow-flow filter that achieves removal and inactivation of infective propagules through a combination of mechanical, physical-chemical, and biological processes (3$5,11,35)$. Slow sand filtration has proven effective against bacterial, fungal, and viral pathogens of recirculating hydroponic systems $(2,4,5,11)$ but requires several large, slow-flow sand filter units to handle the large nutrient solution flows encountered in commercial greenhouses.

A second approach to the control of zoosporic pathogens in recirculating hydroponic systems has been the use of cross-flow membrane filter systems that rapidly remove suspended propagules from nutrient solutions. The primary advantages of crossflow membrane filtration over slow-sand filtration are smaller system size, lower complexity, and reduced costs of membrane 
filtration systems $(8,35)$. Membrane filters have been used effectively to remove suspended infective propagules of fungal (14, $15,26,27)$, bacterial (22), and nematode (20) pathogens from recirculating hydroponic nutrient solutions and irrigation water. In contrast, viral pathogens can only be removed from hydroponic solutions by the use of ultrafiltration systems with pore sizes down to $0.001 \mu \mathrm{m}$ (18). The best results were obtained when two or more membrane filters were used in series $(14,15,20,22,27)$. The primary disadvantage of membrane filters is that they are generally more effective against fungal root pathogens than bacterial or viral pathogens $(14,15,27)$. In addition, as pore sizes of filtration systems are reduced, clogging of filter membranes can increase the potential for system failure or create high maintenance costs (20). Membrane filtration and ultrafiltration systems have been used successfully in the pharmaceutical industry to purify liquid drugs and reagents $(19,32)$.

The primary objective of the current research was to evaluate low-cost cross-flow membrane filter technologies for controlling zoosporic root pathogens in hydroponic systems containing 100 to 1,000 liters of nutrient solution. Large-scale systems were not deemed practical due to the very high nutrient solution flow rates and volumes required in commercial greenhouses. However,

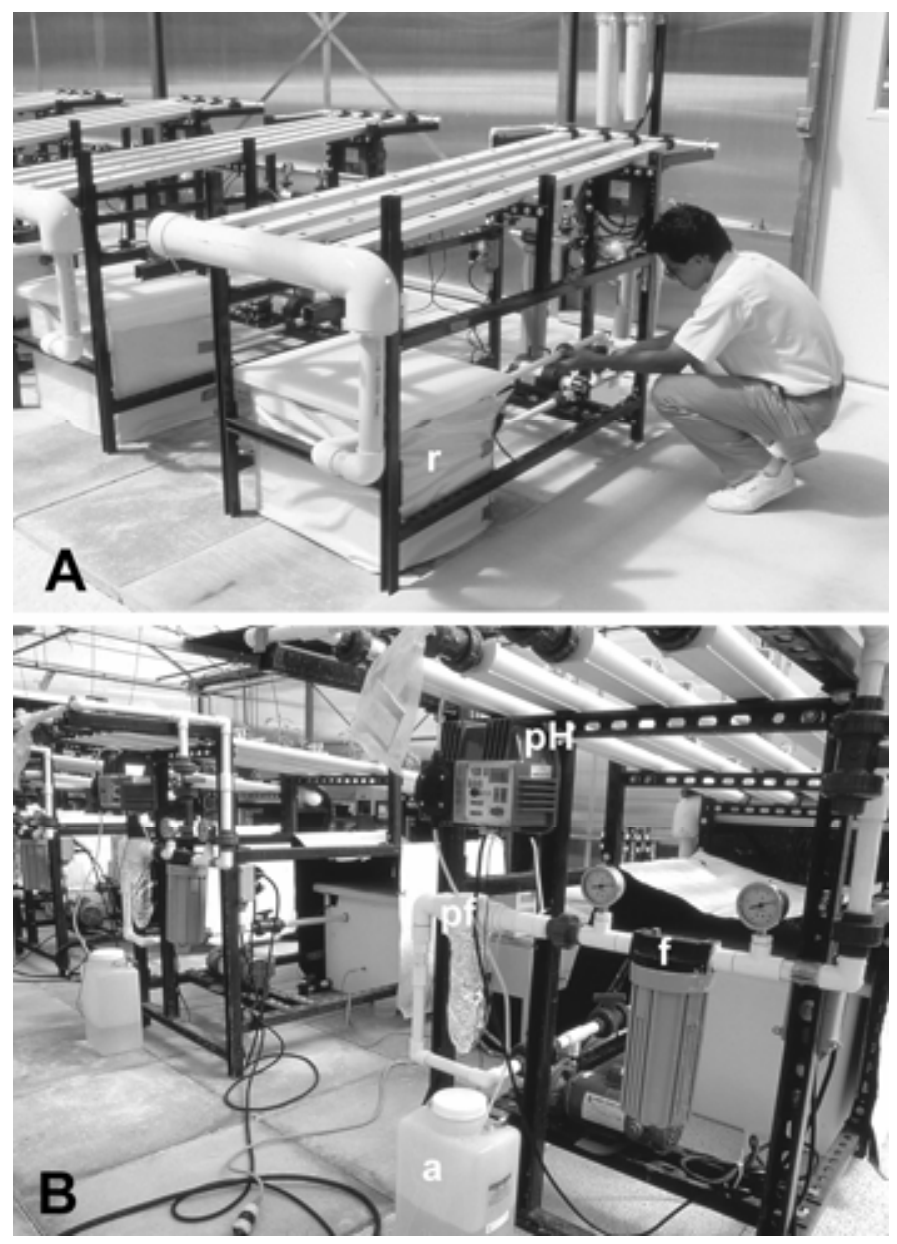

Fig. 1. Six nutrient film technique (NFT) hydroponic systems were used to evaluate cross-flow membrane filters for the suppression of root rot in pepper plants caused by Pythium myriotylum. A, Four troughs per NFT system were placed on the tops of metal structures and drained to 100-liter reservoirs (r). The reservoir tanks and the NFT drain lines were shielded with opaque plastic or greenhouse shade cloth (not shown) to reduce the thermal loading from solar irradiation. B, The filter (f) housings were placed on the back of the NFT systems and used $100-\mu \mathrm{m}$ prefilters (pf) to screen out root and leaf debris from the recirculating nutrient solutions. Pressure gauges were configured at preand post-filter locations to monitor the clogging of all filters. The hydrogen ion concentrations $\left[\mathrm{H}^{+}\right]$of the nutrient solutions were regulated by an analog $\mathrm{pH}$ controller drawing $0.5 \mathrm{M} \mathrm{H}_{2} \mathrm{SO}_{4}$ from a 5-liter acid (a) container. small-scale filter systems might prove economical for hobby hydroponic growers and small-scale commercial hydroponic facilities. The root pathogen Pythium myriotylum Drechsler was chosen for these experiments because it was a frequent pathogen of both pepper and lettuce plants in the small-scale hydroponic systems on display at The Land, Epcot, Lake Buena Vista, FL; a 1.5-acre hydroponic exhibit in Central Florida. Epiphytotics were very common during late spring and summer months and were often eliminated only by shutting down the hydroponic units and conducting system-wide sanitation efforts. Membrane filtration was explored to determine whether it would provide protection from zoosporic pathogens in individual hydroponic units, thus giving greater latitude in scheduling routine shut-down and sanitation of recirculating hydroponic systems. Control of bacterial or viral pathogens transmitted through the nutrient solution was not a priority in this research.

\section{MATERIALS AND METHODS}

Hydroponic systems. Hydroponic solutions were composed of the following inorganic salts: $4.51 \mathrm{mM} \mathrm{Ca}\left(\mathrm{NO}_{3}\right)_{2} \cdot 4 \mathrm{H}_{2} \mathrm{O}, 3.48$ $\mathrm{mM} \mathrm{KNO}{ }_{3}, 1.00 \mathrm{mM} \mathrm{KH}_{2} \mathrm{PO}_{4}, 1.65 \mathrm{mM} \mathrm{MgSO}_{4} \cdot 7 \mathrm{H}_{2} \mathrm{O}, 37.0 \mu \mathrm{M}$ $\mathrm{H}_{3} \mathrm{BO}_{4}, 7.28 \mu \mathrm{M} \mathrm{MnSO}{ }_{4} \cdot \mathrm{H}_{2} \mathrm{O}, 4.59 \mu \mathrm{MnSO}_{4} \cdot 7 \mathrm{H}_{2} \mathrm{O}, 3.05 \mu \mathrm{M}$ $\mathrm{CuCl}_{2} \cdot 2 \mathrm{H}_{2} \mathrm{O}, 0.0074 \mu \mathrm{M}\left(\mathrm{NH}_{4}\right)_{6} \mathrm{Mo}_{7} \mathrm{O}_{24} \cdot \mathrm{H}_{2} \mathrm{O}$, and iron provided by equimolar concentrations $(89.5 \mu \mathrm{M})$ of $\mathrm{FeCl}_{3} \cdot 6 \mathrm{H}_{2} \mathrm{O}$ and diethylenetriaminepentaacetic acid (25). Chemicals were mixed from reagent grade salts obtained from Sigma-Aldrich (St. Louis). The electrical conductivity of the full-strength nutrient solution was $1,700 \mu \mathrm{S} \mathrm{cm}$. For each NFT system and each experiment, 100 liters of nutrient solution was placed within separate polypropylene reservoirs.

The design of the NFT systems were based on the work of Nelson (21). Six independent NFT hydroponic systems (Fig. 1) were constructed with Kendorff stainless steel supports (Grainger Supplies, Orlando, FL) that were cut and joined by appropriately sized steel bolts. All NFT units were placed within a research greenhouse fitted with evaporative-cooling and covered by 6-mil polypropylene transparent greenhouse roofing material. Four PVC hydroponic NFT channels (Rehau Inc., Leesburg, VA) were fitted on the upper surfaces of the metal support structures and connected to 100-liter nutrient solution reservoirs by PVC piping. All NFT troughs were plumbed with separate valves in order to individually control the nutrient flow rates for each NFT channel. One-quarter horsepower (1/4 hp) centrifugal pumps were used to recirculate nutrient solutions in separate NFT systems. Temperatures of nutrient solutions were regulated using three Lauda water chillers (model Lauda RMS-20; Brinkman Scientific, Westbury, NY) that circulated chilled or heated water through 6-mm-diameter stainless steel tubing placed within nutrient solution reservoirs. Each water chiller provided temperature control for two adjacent NFT systems. Root temperatures in the small NFT systems for all experiments were maintained at $30^{\circ} \mathrm{C}\left( \pm 1^{\circ} \mathrm{C}\right)$. In order to assist in reducing the thermal loads in the nutrient reservoirs, $80 \%$ greenhouse shading material and opaque polyvinyl sheeting were used to shade nutrient reservoirs and PVC plumbing on the fronts of the NFT units (Fig. 1A; piping shown but not shadecloth). Nutrient flow started at the 100-liter reservoirs and then passed the following devices: (i) through the 1/4-hp centrifugal pumps, (ii) through a $100-\mu$ m clear polyvinyl screened mesh called a prescreen, (iii) through the filters being tested for efficacy in removing zoospore cysts from the nutrient stream, (iv) past a post-filter sampling port, (v) up and through the valves used to control flow rates to individual NFT channels, (vi) downstream through the NFT channels, and (vii) back to the 100 -liter reservoirs. The flow rate was $\approx 20$ liters/min, depending on system parameters and valve settings. The standard operating pressure was maintained at $0.844 \mathrm{~kg} / \mathrm{cm}^{2}$ (12 psi), as measured prior to the first filter, by using a backstreaming valve on a nu- 
trient solution return line immediately after the 1/4-hp pump. The backstreaming valves and return lines were the primary methods used to regulate line pressures in the NFT systems, and they provided significant mixing of nutrient solutions within reservoirs. Submersible $\mathrm{pH}$ sensors were inserted into nutrient solution reservoirs and used to regulate the hydrogen ion concentrations $\left[\mathrm{H}^{+}\right]$of individual NFT systems. When required, the $\mathrm{pH}$ controller (Cole-Parmer, Vernon Hills, IL) injected $0.5 \mathrm{M} \mathrm{H}_{2} \mathrm{SO}_{4}$ in 5-ml increments into the nutrient reservoirs. The accuracy of the $\mathrm{pH}$ controller would keep the $\left[\mathrm{H}^{+}\right]$to within 0.2 units of desired set points of $\mathrm{pH} 4.5$ to 6.5 .

For most experiments, a single filter housing was installed in the NFT systems (Fig. 1B). Quick-disconnect PVC fittings were used to swap out the filter housings required for different brands of filters. However, a series of experiments was conducted to determine whether a double-filter configuration was more efficient than just a single filter. During the dual-filter experiments, the PVC plumbing on the back of each NFT system was reconfigured as required to accommodate the extra filter housing (not shown). All experiments described below used new filters at the start of each test, thus avoiding potential cross-contamination among experiments.

The NFT systems were sterilized and cleaned to inactivate motile zoospores or zoospore cysts after completing each experiment. First, $500 \mathrm{ml}$ of household bleach $(6 \% \mathrm{NaClO})$ was added to the NFT reservoirs and allowed to recirculate for $60 \mathrm{~min}$. The NFT channels were removed, submersed in a trough of tap water containing 1 liter of household bleach per 32 liters of water, and scrubbed to remove any adhering grime or algal growth. After sterilization, all components of the NFT system were thoroughly rinsed with three to four changes of tap water. And finally, solutions of $0.01 \mathrm{M}$ sodium thiosulfate were added to the reassembled NFT systems and circulated to neutralize any residual $\mathrm{NaClO}$; a final rinse with tap water was used to complete the sterilization process.

Preparation of inoculum. Isolates of $P$. myriotylum were obtained from infected lettuce (Lactuca sativa L., cv. Ostinata) roots grown in hydroponic raceway systems. Preliminary experiments used lab cultures of $P$. myriotylum maintained continuously on V8 agar (6). However, within 6 to 8 weeks of routine cultivation, cultures of $P$. myriotylum lost the ability to produce sporangia and motile zoospores. Thus, throughout the experiments described below, in situ cultures of $P$. myriotylum were maintained in separate hydroponic systems. Fresh isolates of $P$. myriotylum were started on V8 agar from infected plants every 3 weeks to maintain zoospore production. Taxonomic affiliations of all isolates were confirmed using the keys of van der Plaats-Niterink (33).

Encysted zoospores (i.e., cysts) of P. myriotylum were prepared by growing the fungus on V8 agar $(100 \mathrm{ml}$ of $\mathrm{V} 8$ juice, $15 \mathrm{~g}$ of agar, and $1 \mathrm{~g}$ of $\mathrm{CaCO}_{3}$ per liter of media) at $30^{\circ} \mathrm{C}$ for $48 \mathrm{~h}$, transferring 1-cm-diameter plugs collected from the V8 agar into 1 liter of sterile deionized water (SDIW), and incubating the zoospore cultures for $24 \mathrm{~h}$ at $30^{\circ} \mathrm{C}$ in a rotary shaker water bath (50 rpm in the dark). Motile zoospores were harvested by passing the slurry of V8 agar and SDIW through three layers of cheesecloth into a second presterilized flask. Motile zoospores were encysted by rapid rotation of the spore suspensions with magnetic stir bars for $10 \mathrm{~min}$. Samples from the cyst suspensions were removed and quantified by direct counts in a hemacytometer, and suspensions were either diluted or concentrated by centrifugation to achieve desired spore densities for filtration tests.

Two assay techniques for estimating cyst densities were used throughout these experiments. First, for the single-filter assays (see below), $100 \mathrm{ml}$ of nutrient solution was collected for each sample and assayed by pipetting 20,50- $\mu$ l subsamples onto water agar (Difco Bacto Agar at $15 \mathrm{~g} /$ liter), incubating the cultures at $25^{\circ} \mathrm{C}$ for $24 \mathrm{~h}$, and staining the germinated zoospore cysts with $0.5 \%$ trypan blue in a lactic acid $(20 \mathrm{ml})$, glycerol $(40 \mathrm{ml})$, and water $(20 \mathrm{ml})$ solvent. The minimum detection limit in the "micro- drop assay" was 1,000 zoospore cysts/liter. Second, to estimate the cyst densities in the nutrient solution samples collected from the double-filter assays (see below), $500 \mathrm{ml}$ of nutrient solution was collected from either the main hydroponic reservoirs or from sample ports immediately after all filter housings (Fig. 1). Each sample was handled separately. The nutrient solutions were filtered through $47-\mathrm{mm}$-diameter gridded filter paper disks $(0.45-\mu \mathrm{m}$ pore size) that were then incubated on water agar maintained at $25^{\circ} \mathrm{C}$ for $24 \mathrm{~h}$. The filters were not inverted on the water agar. After $24 \mathrm{~h}$, zoospore cysts were stained with the $0.5 \%$ trypan blue solution. The minimum detection limit of the filtration assay was two zoospore cysts per liter. The second assay was developed to increase the sensitivity of estimating the numbers of zoospore cysts penetrating cross-flow filters.

Filter membrane designs and pore sizes. Four cross-flow membrane filter brands were tested for efficiencies in removing zoospore cysts from hydroponic solutions. Two filter brands (Polypure and Absolife) were manufactured by Gelman Sciences (Ann Arbor, MI) and two filter brands (Honeycomb and Polymate) were manufactured by Parker Hannifin Corp. (Oxnard, CA). All four filter brands were constructed of polypropylene fibers that were either woven cotton-fiber strands (Honeycomb) or pleated polypropylene membranes (Polypure, Absolife, and Polymate). Scanning electron microscopy (SEM) images of all filters (e.g., Fig. 2A, Polymate filter) revealed a complex matrix of inter-
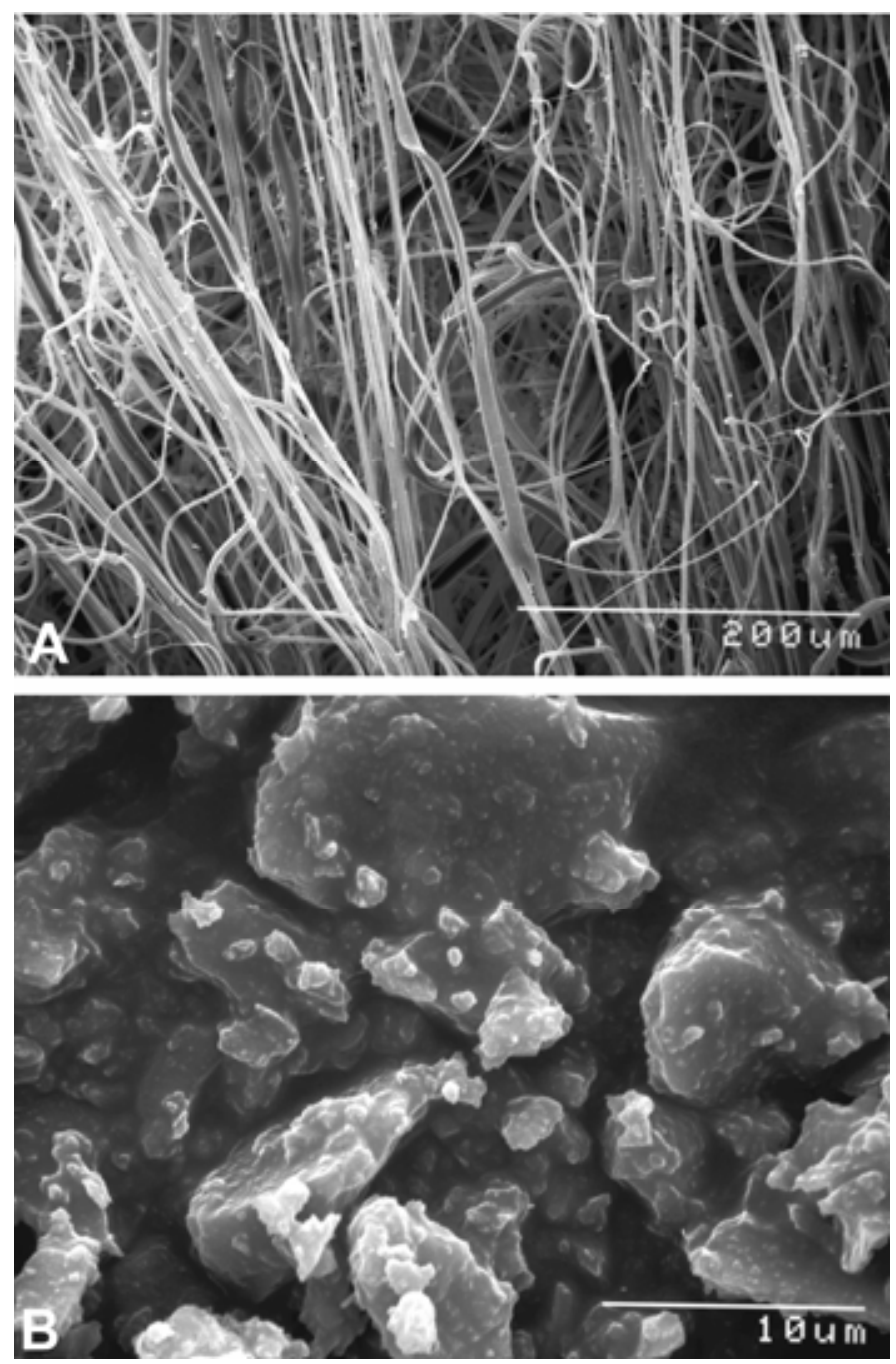

Fig. 2. A, Polymate cross-flow filter membranes were composed of tightly woven polypropylene fibers bonded to a polypropylene pleated drainage layer (not shown). B, Diatomaceous earth was used by the manufacturers to rate the nominal efficiencies of all filters. 
woven fibers that entrapped particulates and zoospore cysts directly. The industry method for rating filters is to use a finely ground matrix of diatomaceous earth (Fig. 2B) that is forced through filter membranes at standardized pressures and flow rates. The diatomaceous earth is composed of rigid and highly angular particles.

Filters were tested alone or in a dual-filter configuration to determine the best filter or set of filters that would remove suspended zoospore cysts from the nutrient streams of the NFT systems. For the single-filter assays, each brand (as listed above) used a style of sealing the filter into the housing called a knife-edge fit. A knife-edge fit used a filter housing with plastic ridges that would seal against rubber gaskets on each side of the filter. In contrast, the double-filter assays used both the knife-edge sealing technology and other filters that used two O-rings placed around male flanges that fit into the filter housing. The O-ring technology was advertised by the manufactures as delivering a tighter fit than the knife-edge technology and, thus, presumably a reduced risk of accidental blow-by of the filter during operation.

Typical operating conditions for all filters did not exceed 1.5 bars of in-line pressure (filters were rated up to 2 to 4 bars) and $35^{\circ} \mathrm{C}$ (filters were rated at 60 to $115^{\circ} \mathrm{C}$ ). For the single-filter assays, similar pore-size ratings were used for Honeycomb (1, 5, 10, and $20 \mu \mathrm{m})$, Polypure $(1,5,10$, and $30 \mu \mathrm{m})$, Polymate (1, 5, 10 , and $30 \mu \mathrm{m})$, and Absolife $(1.2,4.5$, and $10 \mu \mathrm{m})$ filters. In the double-filter assays, combinations of Polymate knife-edge (Poly$\mathrm{K})$, Polymate O-ring (Poly-O), Absolife knife-edge (Abso-K), and Absolife O-ring (Abso-O) filters were used in the range of 0.5- to 4.5- $\mu$ m nominal pore size.

Filter-efficiency experiments. Individual NFT units were fitted with the brands and pore sizes of the filters listed above; filter brands were tested separately. Fresh nutrient solution (100 liters) was added to individual NFT systems, allowed to recirculate through the NFT channels, and permitted to stabilize at $30^{\circ} \mathrm{C}$ for $2 \mathrm{~h}$. The bypass valves were then opened so that $100 \%$ of the nutrient solutions would be pumped from the reservoirs through the centrifugal pumps and back to the reservoirs. Suspensions of zoospore cysts were quantified and the appropriate amounts added to each NFT reservoir to achieve densities of $\approx 400$ to 450 viable cysts $/ \mathrm{ml}$. The zoospore cysts were mixed for $60 \mathrm{~s}$ in the reservoirs, and $\mathrm{T}=0$ samples were collected for estimating the numbers of viable cysts in the nutrient solution. Then, the bypass valves were partially closed to achieve in-line pressures of $0.844 \mathrm{~kg} / \mathrm{cm}^{2}$ just prior to the filters. After an additional $60 \mathrm{~s}$, a second set of samples was collected from the post-filter sample ports on each NFT system. Finally, nutrient solution samples from the NFT reservoirs were collected at 30 and 120 min after initiating the filtration process. Numbers of viable zoospore cysts were estimated as described above.

Two series of experiments were conducted in separate trials. First, single filters (Absolife, Honeycomb, Polymate, and Polypure) were tested for efficiencies in removing zoospore cysts from nutrient streams. Second, Poly-K, Poly-O, Abso-K, and Abso-O filters were used in dual configurations with nominal pore sizes of 0.5 to $4.5 \mu \mathrm{m}$. All filter assays were conducted with no plants in the NFT systems and, thus, represent the capabilities of the filters in removing zoospore cysts from the nutrient streams without plant roots contributing to the removal process.

Single-filter plant bioassays. Two of the four filters were selected for testing with pepper plants in the NFT systems. Honeycomb filters (nominal pore size of $1,5,10$, and $20 \mu \mathrm{m}$ ) were chosen because of their lower cost per filter compared with all other brands. Polymate filters (nominal pore size of 1, 5, 10, and $30 \mu \mathrm{m}$ ) were chosen for their high efficiency in removing zoospore cysts from the nutrient stream. Polypure and Absolife filters were not chosen for these experiments because (i) Polypure filters were not as effective as Polymate filters in removing zoospore cysts from nutrient streams and (ii) Absolife filters had a tendency to clog during the assays.
Four NFT systems were configured with sets of either Polymate or Honeycomb filters (i.e., each filter brand was run separately). The two remaining NFT systems did not have filters inserted in the nutrient streams; one system was infested with zoospore cysts and served as a positive control and one system was not infested with cysts and served as a negative control.

Pepper plants (Capsicum annuum, L.), cv. Hungarian Wax were germinated for 3 weeks in Grodan Rockwool seedling cubes (A. H. Hummert Seed Co., Earth City, MO). Sixteen seedlings (four per NFT trough) were transplanted into each NFT system and allowed to grow an additional 3 weeks prior to adding zoospore cysts to the nutrient solution reservoirs. Zoospore cysts were prepared as described above and then added to the NFT systems at the rate of $1.5 \times 10^{7}$ cysts per 100 liters of nutrient solution $(150$ cysts $/ \mathrm{ml})$. The NFT reservoirs were allowed to mix for $60 \mathrm{~s}$, and then the by-pass valves were opened and adjusted to yield line pressures of $0.844 \mathrm{~kg} / \mathrm{cm}^{2}$. The NFT systems were then maintained for an additional 4 weeks in which the $\left[\mathrm{H}^{+}\right]$was maintained at $\mathrm{pH} 6.5$ ( \pm 0.2 units).

At harvest, plants were measured for shoot and root fresh weights, percentage of canopies exhibiting wilt symptoms, percentage of roots with visual necrosis, and rated for root symptoms. Each NFT system was handled as a single experimental unit, and the experiments were conducted a total of five times $(n=$ 5 for all data). Wilt symptoms (Fig. 3A) were recorded as positive if any signs of leaf wilting were observed in the canopies. Healthy roots (Fig. 3B) exhibited no necrosis, but some slight discoloration of roots was typically observed immediately adjacent to the rockwool cubes. The slightly discolored roots adjacent to rockwool cubes were assayed from all noninfested NFT systems to determine whether cross-contamination by $P$. myriotylum had occurred. Discolored roots were excised and plated onto PAR media (adapted from Kannwischer and Mitchell) (16) composed of cornmeal agar (17 g/liter) supplemented with pimaricin (10 mg/liter), ampicillin (0.25 g/liter), and rifampicin (10 mg/liter) (all chemicals from Sigma-Aldrich). Excised roots from healthy control plants were incubated for $24 \mathrm{~h}$ at $30^{\circ} \mathrm{C}$. Diseased pepper roots (Fig. 3C) were often collapsed and moribund, and would slough off root systems if mechanically probed. Each root system was rated for the severity of disease based on a rating scale of 0 to 5. Ratings were assigned according to the following symptoms: $0=$ no visual disease symptoms, $1=$ up to $10 \%$ of roots exhibiting symptoms, $2=10$ to $30 \%$ with symptoms, $3=30$ to $70 \%$ with symptoms, $4=70$ to $90 \%$ with symptoms, and $5=90$ to $100 \%$ with symptoms.

Insect vacuum traps were used to collect flying insects in the research greenhouse in order to confirm that insect transmission of P. myriotylum oospores did not occur between NFT units, as reported for shore flies in other hydroponic systems (13). Shore flies but not fungus gnats were present in weekly samples. Twice weekly, shore flies were collected and directly plated onto PAR media. Assayed insect bodies on PAR were then incubated for $72 \mathrm{~h}$ at $30^{\circ} \mathrm{C}$.

Effects of $\left[\mathrm{H}^{+}\right]$on bacterial clogging of single Polymate filters. Polymate filters with 1 - or 5- $\mathrm{mm}$ nominal pore-size ratings exhibited a tendency to partially clog during the 4-week singlefilter plant bioassays described above. In addition, because a $\left[\mathrm{H}^{+}\right]$ of the nutrient solution above $\mathrm{pH} 6.7$ would induce the precipitation of salts, and because the operating $\left[\mathrm{H}^{+}\right]$of the NFT systems was set at $\mathrm{pH} 6.5$, it was hypothesized that the operational $\left[\mathrm{H}^{+}\right]$ was too close to the point at which salts would precipitate. In order to determine whether this effect could be eliminated, a series of tests were conducted in which pepper plants were grown for 8 weeks in NFT systems fitted with 1- $\mu$ m Polymate filters and maintained at $\mathrm{pH} 4.5,5.5$, or 6.5 . The hypothesis being tested was that $\left[\mathrm{H}^{+}\right]$at $\mathrm{pH} 4.5$ or 5.5 would (i) suppress salt precipitation, (ii) possibly suppress bacterial growth, and (iii) extend filter life by reducing clogging. Typically, hydroponic nutrient solutions are 
maintained near $\mathrm{pH} 6.5(21,25)$ but can be operated down to $\mathrm{pH}$ 4.5 if aluminum ions are not abundant (A. C. Schuerger, unpublished data).

Six NFT systems were prepared as described above. Sixteen 3-week-old pepper seedlings were transplanted into each NFT system and the $\left[\mathrm{H}^{+}\right]$concentration adjusted to desired set points. The plants were maintained for an additional 8 weeks and pruned as necessary to prevent lodging of plants. Every 7 days, $100 \mathrm{ml}$ from each NFT reservoir was collected and processed to estimate the numbers of total suspended bacteria per milliliter per NFT system, and the line pressure for each filter was measured. $\mathrm{Nu}-$ trient solutions were serially diluted and all dilutions plated onto nutrient agar (6). Each $\left[\mathrm{H}^{+}\right]$was replicated twice per repetition, and the experiment was conducted four times $(n=8)$.

Double-filter plant bioassays. Polymate O-ring-style filters at nominal pore-sizes of 1 and $0.5 \mu \mathrm{m}$ were selected for double-filter plant bioassays. The NFT systems (Fig. 1) were reconfigured with two separate filter housings per NFT system. The filters were placed in the NFT plumbing such that the Polymate $1-\mu \mathrm{m}$ filter preceded the $0.5-\mu \mathrm{m}$ filter. Pressure gauges were inserted in the nutrient streams such that the pre- and post-filter pressures could be monitored for both filters. After inoculation, the bypass valve was adjusted such that the pressure gauge before the first filter would read $0.844 \mathrm{~kg} / \mathrm{cm}^{2}$.

Pepper plants were grown as described above and transplanted into NFT systems after 3 weeks. Plants were allowed to establish mature canopies for an additional 3 weeks, and then NFT systems were infested with zoospore cysts at the rate of $2.0 \times 10^{7}$ per 100 liters $(200$ cysts $/ \mathrm{ml})$. The $\left[\mathrm{H}^{+}\right]$was maintained at $\mathrm{pH} 5.5$ throughout the experiments. Noninfested NFT systems served as negative controls and infested but no-filter NFT units served as positive controls. Infected and noninfected pepper plants were maintained for an additional 4 weeks. At harvest, plants were measured for shoot and root fresh weights, percentage of canopies exhibiting wilt symptoms, percentage of roots with visual necrosis, and rated for root symptoms. Each treatment was replicated twice per repetition and the experiment was conducted four times $(n=8)$.

SEM of entrapped zoospore cysts on Polymate filters. SEM images were collected from Polymate $1-\mu \mathrm{m}$ filters used in NFT systems in order to characterize the condition of zoospore cysts entrapped in filters. Zoospore cysts were added to an NFT system configured with a single Polymate $1-\mu \mathrm{m}$ filter at the rate of $2.0 \times$ $10^{7}$ cysts per 100 liters $(200$ cysts/ml). A second NFT system served as a noninfested control. No plants were present at the times of cyst entrapment in filters. Both infested and noninfested systems were assayed after $60 \mathrm{~min}$ of operation following the addition of zoospore cysts to the infested NFT unit. The experiment was repeated three times.

A minimum of 12 pieces of filter membranes were dissected from each NFT system for each repetition of the experiment. The filter sections were excised and handled in such a way as to maintain the orientation of the outside surface of the filters. Excised filter sections were fixed for $24 \mathrm{~h}$ at $4^{\circ} \mathrm{C}$ in $3 \%$ glutaraldehyde in a $0.07 \mathrm{M}$ phosphate buffer titrated to $\mathrm{pH}$ 7.2. The samples were rinsed three times with phosphate buffer $\left(\right.$ at $\left.4{ }^{\circ} \mathrm{C}\right)$ and post-fixed in similarly buffered $1 \%$ osmium tetroxide. Both fixatives were obtained from Ted Pella, Inc. (Redding, CA). Osmium-fixed filter pieces were rinsed three times in phosphate buffer $\left(\right.$ at $\left.4^{\circ} \mathrm{C}\right)$, warmed to room temperature, and serially diluted in a $10 \%$ graded ethanol series. Samples were then critical point dried in liquid $\mathrm{CO}_{2}$ and coated with gold-palladium in a sputter coater. Samples were imaged in a Hitachi S-530 SEM scope (Hitachi High Technologies America, Inc., Pleasanton, CA).

Statistics. Statistical analyses were conducted with version 8.0 of the PC-based Statistical Analysis System (SAS) (SAS Institute, Inc., Cary, NC). Percentage data that exceeded a range of $40 \%$ were arcsine transformed prior to analysis in order to induce homogeneity of treatment variances (based on discussions by Steel and Torrie [31]). All other data were not transformed prior to analysis. Data in tables are presented as untransformed values. Significance for each set of experimental data was based on analysis of variance (PROC GLM) followed by protected Fisher's least significant difference tests $(P \leq 0.05)$. All treatments were randomly assigned to NFT units.

\section{RESULTS}

Cross-contamination of NFT systems. Two methods were effectively used to evaluate whether cross-contamination of NFT systems occurred during these experiments. First, routine sani-
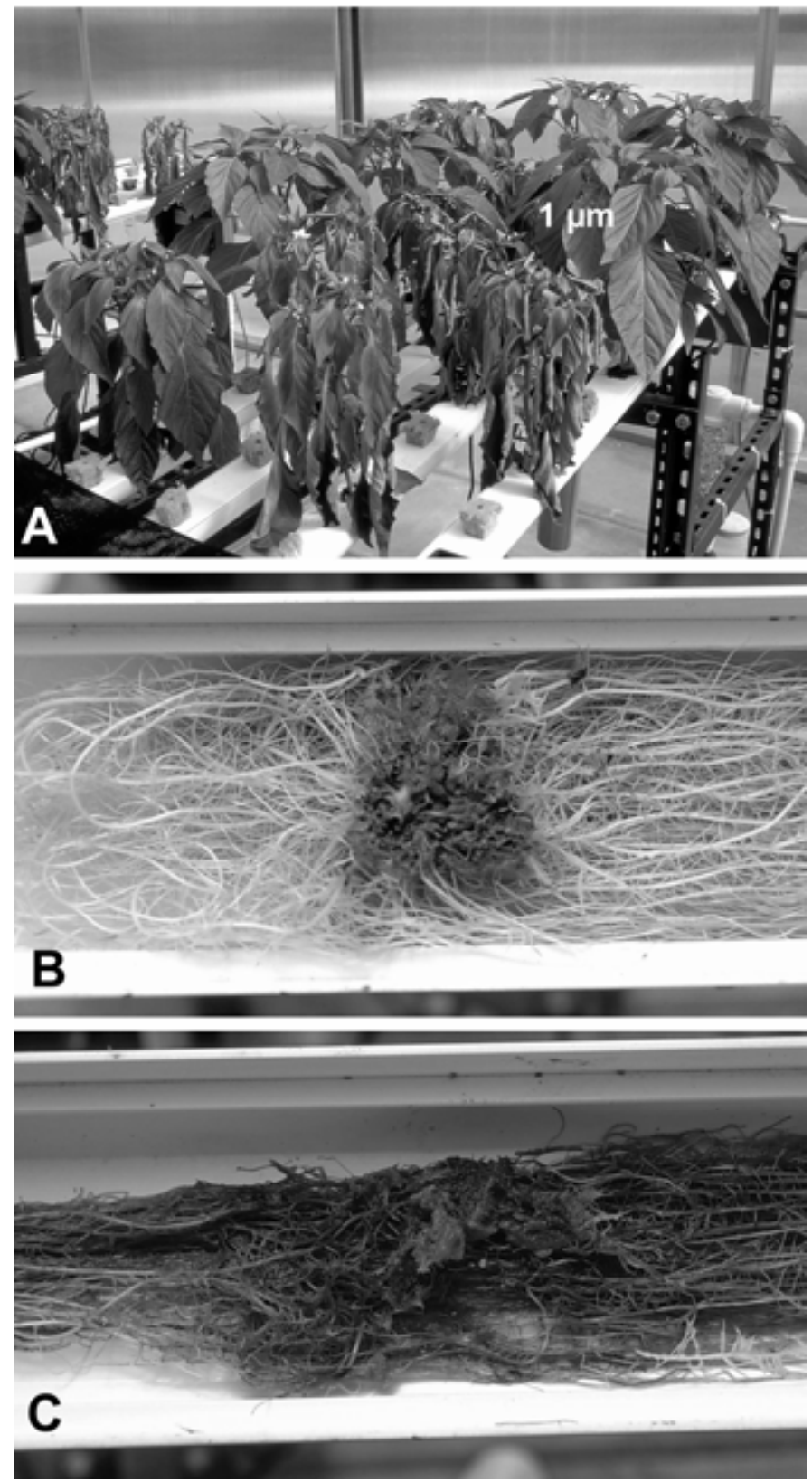

Fig. 3. Nutrient film technique (NFT) system with pepper plants (Capsicum апnиит, cv. Hungarian Wax) infected with Pythium myriotylum. A, Wilting pepper plants growing in an NFT system infested with zoospore cysts of $P$. myriotylum. The nutrient solution passed through a single 1.0- $\mu \mathrm{m}$ Polymate filter; $\approx 50 \%$ of plants wilted even though the filter rating was significantly smaller than the normal range of zoospore cysts (i.e., 8 to $10 \mu \mathrm{m}$ in diameter). B, Healthy, noninfected control roots of a pepper plant diverging from a rockwool cube used to germinate seedlings. C, Moribund roots of a pepper plant infected with P. myriotylum. 
tation of the NFT systems using $6 \% \mathrm{NaClO}$ resulted in only one observable cross-contamination event in 5 years of research. The cross-contamination event was observed when pepper plants in two of six NFT units exhibited symptoms after transplanting seedlings but prior to infesting the nutrient solutions with zoospore cysts. Excised roots from the symptomatic plants were positive for $P$. myriotylum. The cross-contaminated experiment was deleted from the data. In all other plant assays, no root or shoot symptoms were observed on peppers prior to infesting nutrient solutions with zoospore cysts. Furthermore, all excised roots from healthy plants obtained from negative-control NFT units (i.e., no zoospore cysts added) were negative for P. myriotylum. Second, shore flies were regularly assayed for the presence of ingested infective propagules of $P$. myriotylum, as has been reported for oospores of $P$. aphanidermatum in hydroponic systems within other greenhouses (13). No mycelia grew from shore fly bodies plated on PAR media throughout the experiments. Based on negative results from healthy-root and shore-fly assays, routine crosscontamination of NFT systems did not occur during the course of these experiments.

Single-filter efficiency tests. All Honeycomb filters (Fig. 4A) and all Polypure filters (Fig. 4B) failed to fully remove zoospore cysts from the nutrient streams on the first pass through the filters, and most filters generally failed to scrub zoospore cysts from the
NFT reservoirs even after $30 \mathrm{~min}$. Honeycomb and Polypure $1-\mu \mathrm{m}$ filters were capable of scrubbing zoospore cysts from the NFT nutrient reservoirs after $30 \mathrm{~min}$. In contrast, Polymate filters (Fig. 4C) rated at 1, 5, or $10 \mu \mathrm{m}$ and Absolife filters (Fig. 4D) rated at 1.2 or $4.5 \mu \mathrm{m}$ were effective in removing zoospore cysts from the nutrient streams as measured from the post-filter (PF) samples. In all experiments, the numbers of recovered zoospore cysts decreased over time in the NFT systems that did not have filters present during the assays (Fig. 4, rated as "0"). Thus, some loss in cyst numbers could be attributed to the mechanical stresses encountered within the centrifugal pumps used in the NFT plumbing.

Single-filter plant bioassays. Honeycomb and Polymate filters suppressed root disease and canopy wilt only moderately in pepper plants grown in infested NFT systems (Tables 1 and 2), even though the Polymate filters removed zoospore cysts more effectively than Honeycomb filters at any given pore size (Fig. 4). Surprisingly, $1-$ and $5-\mu \mathrm{m}$ filters for both brands failed to dramatically reduce root and canopy symptoms when compared with larger pore sizes of these filters. Root symptoms for plants in NFT systems with both filters were observed first in the positive controls (i.e., infested with zoospore cysts but lacking any filter) within $96 \mathrm{~h}$ after infesting NFT systems with zoospore cysts; plant wilt followed within 10 to 14 days of initial root symptoms.
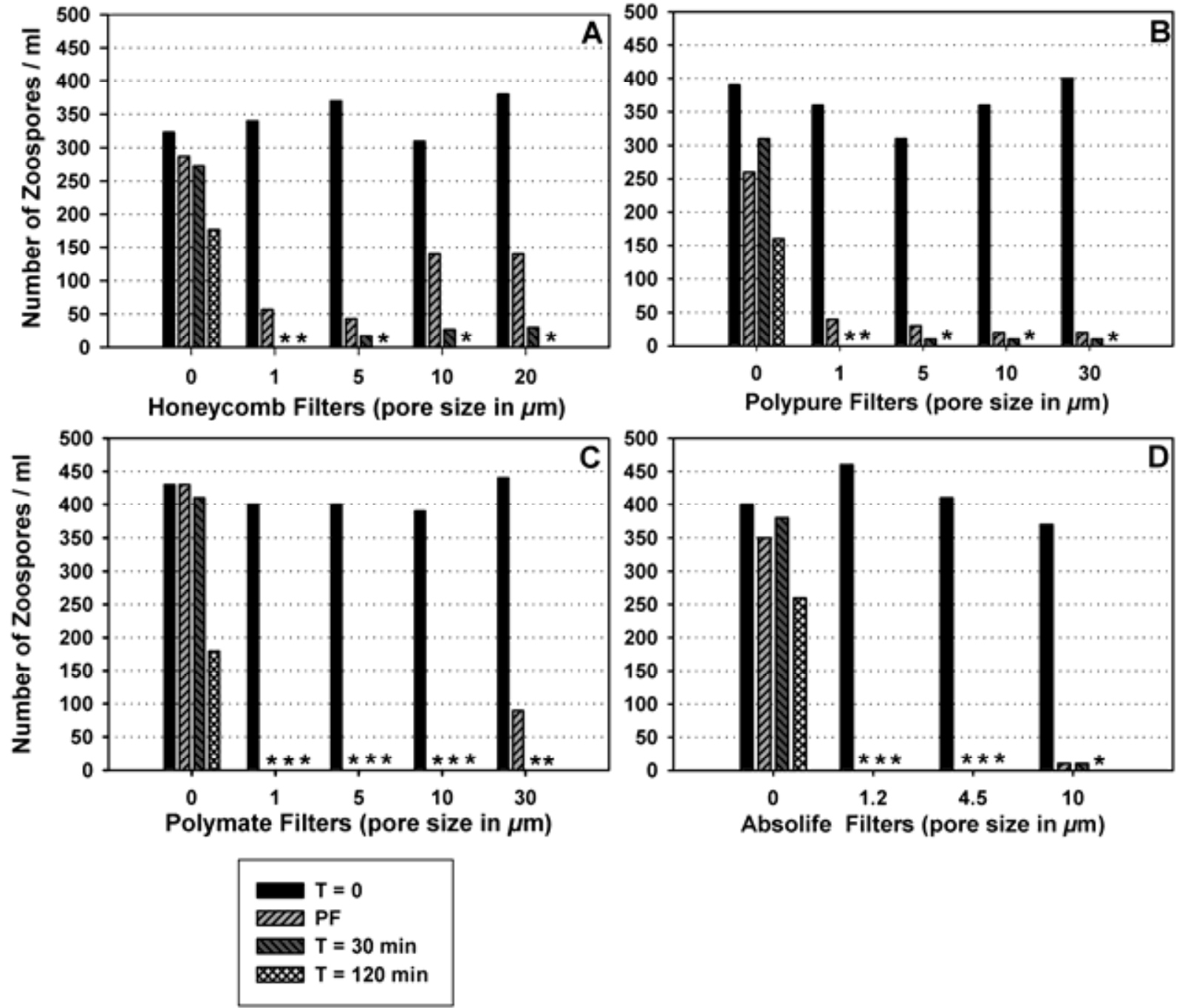

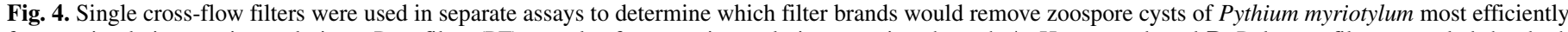

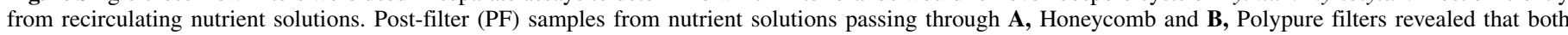

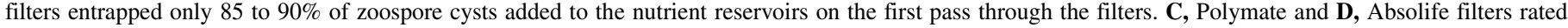

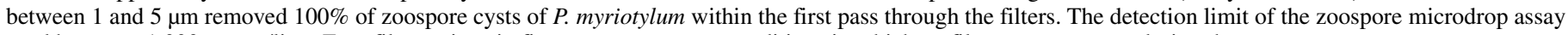
used here was 1,000 spores/liter. Zero filter ratings in figures represent test conditions in which no filters were present during the zoospore cyst assays. 
Root symptoms and plant wilt were generally delayed 4 to 7 days in the 1- and 5- $\mu \mathrm{m}$ filter NFT units when compared with larger pore sizes of 10 to $30 \mu \mathrm{m}$. Thus, smaller filter pore sizes did delay the onset of plant disease but disease levels tended to be similar at the conclusions of the 28-day plant assays. Symptomless roots from infested NFT units were assayed with PAR media for the presence of $P$. myriotylum. In all such assays, the pathogen was recovered from apparently healthy roots. In contrast, symptomless roots in noninfested NFT units were always negative for $P$. myriotylum.

Effects of $\left[\mathrm{H}^{+}\right]$on bacterial clogging of single Polymate filters. During the single-filter plant assays with Honeycomb and Polymate filters, the post-filter pressures generally dropped from 0.844 to $0.563 \mathrm{~kg} / \mathrm{cm}^{2}$ (12 to $8 \mathrm{psi}$ ) during the course of the experiments compared with the prefilter pressures; the smaller the pore sizes of the filters, the greater the pressure drops observed. It was hypothesized that an $\left[\mathrm{H}^{+}\right]$at or below $\mathrm{pH} 5.5$ would suppress bacterial growth and eliminate the precipitation of nutrient salts. Results did not support the conclusion that nutrient solutions maintained at $\mathrm{pH} 4.5$ or 5.5 suppressed suspended bacterial populations in the nutrient solutions when compared with solutions maintained at pH 6.5 (Fig. 5A). Bacterial populations in all NFT systems fluctuated between $10^{4}$ and $10^{6} \mathrm{CFU} / \mathrm{ml}$ for all three $\left[\mathrm{H}^{+}\right]$ tested. In contrast, the post-filter pressures dropped dramatically in NFT systems maintained at $\mathrm{pH} 6.5$ but not in NFT systems maintained at $\mathrm{pH} 4.5$ or 5.5 (Fig. 5B). Thus, the data support the conclusion that bacterial clogging was not a key factor in reducing the post-filter pressures but that salt precipitation at $\mathrm{pH} 6.5$ was the likely cause of the decrease in pressures observed with filters. Based on these results, all subsequent experiments were run at $\mathrm{pH} 5.5$ to suppress the precipitation of salts in the unbuffered nutrient solutions.

Double-filter efficiency tests. Seven combinations of double filters were tested to determine whether $100 \%$ of all zoospore cysts could be effectively removed during a single pass through both filters. The first of two filters effectively reduced the numbers of suspended zoospore cysts by $>99.6 \%$ (Table 3 ). However, the filtration efficiencies for the second filters were more variable. The second filters for (i) Poly-K $(1 \mu \mathrm{m})+$ Poly-K $(1 \mu \mathrm{m})$ and (ii) Poly-O $(1 \mu \mathrm{m})+$ Poly-O $(1 \mu \mathrm{m})$ were only capable of removing $\approx 55 \%$ of the zoospore cysts. In contrast, the second filters for (i)
Poly-K $(1 \mu \mathrm{m})+$ Poly-K $(0.5 \mu \mathrm{m})$ and (ii) Poly-O $(1 \mu \mathrm{m})+$ Poly$\mathrm{O}(0.5 \mu \mathrm{m})$ combinations were able to remove $\approx 97 \%$ of the zoospore cysts on a single pass-through of the double-filter system. The double-filter sets with Absolife filters worked slightly
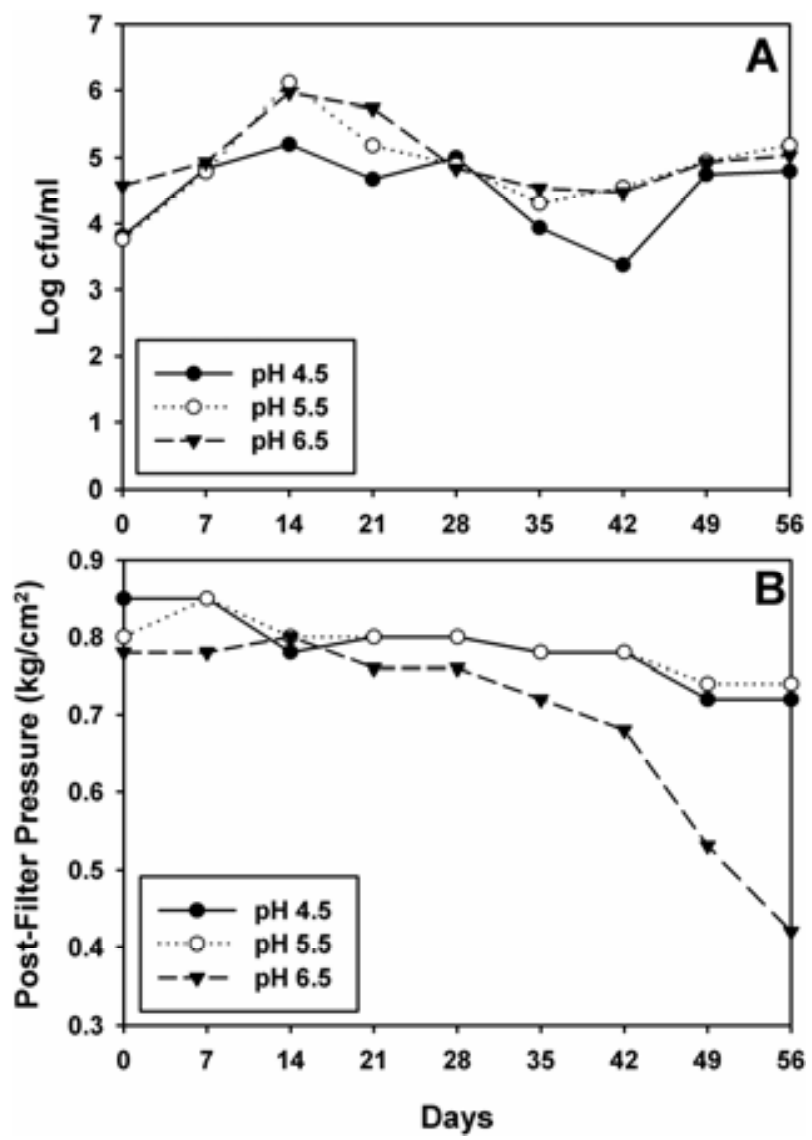

Fig. 5. A, Effects of hydrogen ion concentrations $\left[\mathrm{H}^{+}\right]$of nutrient solutions on bacterial CFUs per milliliter of nutrient solution and $\mathbf{B}$, changes in post-filter pressures measured over 56 days. Polymate filters rated at $1 \mu \mathrm{m}$ were used in all tests.

TABLE 1. Effects of using Honeycomb filters to suppress disease development in peppers caused by Pythium myriotylum ${ }^{\mathrm{y}}$

\begin{tabular}{|c|c|c|c|c|c|}
\hline Treatment $^{\mathrm{z}}$ & Shoot fresh wt. (g) & Root fresh wt. (g) & Root disease rating & Wilt (\%) & Root symptoms (\%) \\
\hline (-) Control & $75.0 \mathrm{a}$ & $35.6 \mathrm{a}$ & $0.0 \mathrm{c}$ & $0 \mathrm{c}$ & $0 \mathrm{c}$ \\
\hline $1 \mu \mathrm{m}$ & $55.5 \mathrm{ab}$ & $27.0 \mathrm{a}$ & $3.0 \mathrm{~b}$ & $44 \mathrm{~b}$ & $65 \mathrm{~b}$ \\
\hline $5 \mu \mathrm{m}$ & $53.2 \mathrm{abc}$ & $24.2 \mathrm{a}$ & $2.9 \mathrm{~b}$ & $55 \mathrm{~b}$ & $70 \mathrm{~b}$ \\
\hline $10 \mu \mathrm{m}$ & $45.3 \mathrm{bc}$ & $18.2 \mathrm{~b}$ & $4.0 \mathrm{ab}$ & $73 \mathrm{ab}$ & $86 \mathrm{ab}$ \\
\hline $20 \mu \mathrm{m}$ & $40.2 \mathrm{bc}$ & $14.8 \mathrm{~b}$ & $4.4 \mathrm{ab}$ & $80 \mathrm{ab}$ & $100 \mathrm{a}$ \\
\hline (+) Control & $24.8 \mathrm{c}$ & $8.8 \mathrm{~b}$ & $5.0 \mathrm{a}$ & $100 \mathrm{a}$ & $100 \mathrm{a}$ \\
\hline
\end{tabular}

y Percentage data were arcsine transformed prior to analysis; all other data were not transformed. All data are presented as untransformed values. Treatment means in columns followed by similar letters were not significantly different based on analysis of variance and protected Fisher's least-significant difference tests $(P \leq$ $0.05, n=5)$.

${ }^{\mathrm{z}}$ Negative $(-)$ control $=$ no filters and noninoculated plants and positive $(+)$ control $=$ no filters but inoculated.

TABLE 2. Effects of using Polymate filters to suppress disease development in peppers caused by Pythium myriotylum ${ }^{y}$

\begin{tabular}{|c|c|c|c|c|c|}
\hline Treatment $^{\mathrm{z}}$ & Shoot fresh wt. (g) & Root fresh wt. (g) & Root disease rating & Wilt (\%) & Root symptoms (\%) \\
\hline (-) Control & $101.1 \mathrm{a}$ & $42.3 \mathrm{a}$ & $0.0 \mathrm{c}$ & $0 \mathrm{c}$ & $0 \mathrm{c}$ \\
\hline $1 \mu \mathrm{m}$ & $67.6 \mathrm{ab}$ & $21.8 \mathrm{~b}$ & $3.1 \mathrm{~b}$ & $49 \mathrm{~b}$ & $67 \mathrm{~b}$ \\
\hline $5 \mu \mathrm{m}$ & $59.1 \mathrm{~b}$ & $19.8 \mathrm{~b}$ & $3.2 \mathrm{~b}$ & $52 \mathrm{~b}$ & $73 \mathrm{~b}$ \\
\hline $30 \mu \mathrm{m}$ & $70.7 \mathrm{ab}$ & $23.5 \mathrm{~b}$ & $3.6 \mathrm{~b}$ & $52 \mathrm{~b}$ & $75 \mathrm{~b}$ \\
\hline (+) Control & $18.8 \mathrm{c}$ & $3.7 \mathrm{c}$ & $5.0 \mathrm{a}$ & $100 \mathrm{a}$ & $100 \mathrm{a}$ \\
\hline
\end{tabular}

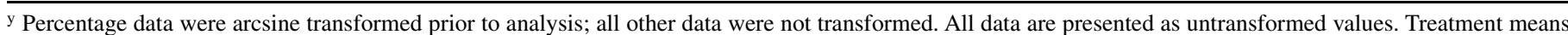
in columns followed by similar letters were not significantly different based on analysis of variance and protected Fisher's least-significant difference tests $(P \leq$ $0.05, n=5)$.

${ }^{\mathrm{z}}$ Negative $(-)$ control $=$ no filters and noninoculated plants and positive $(+)$ control $=$ no filters but inoculated. 
better than the double Polymate $(1+1 \mu \mathrm{m})$ filters but the postfilter pressures continued to decrease during the assays, and the Absolife filters were dropped from further testing.

Double-filter plant bioassays. Based on the double-filter efficiency tests (Table 3), a Polymate O-ring combination of 1 - and $0.5-\mu \mathrm{m}$ filters was used to determine whether a doublefilter configuration could effectively reduce disease incidence and severity. Results indicated that the double-filter combination of Polymate filters rated at 1 and $0.5 \mu \mathrm{m}$ effectively and significantly reduced the incidence and the severity of plant disease caused by $P$. myriotylum (Table 4). Pepper plants in the double-filter NFT systems infested with zoospore cysts were similar to negative control plants in both shoot and root fresh weights. However, root rot symptoms were observed in $2 \%$ of plants present in infested NFT systems with filters, and a few plants did wilt. All assayed symptomatic root tissues were positive for the presence of $P$. myriotylum.

SEM of captured zoospore cysts on filter membranes. Most observed zoospore cysts exhibited nearly uniform spherical shapes of slightly different sizes (Fig. 6A and B). Many zoospore cysts entrapped on the Polymate filters had germinated between the times in which NFT systems were infested and the dissected filters were placed in the SEM fixatives (a period of 60 to $70 \mathrm{~min}$ ) (Fig. 6A, B, and C). In some cases (Fig. 6A and B), zoospore cysts retained spherical integrity after germination and, in other cases (Fig. 6C), germinated zoospore cysts appeared partially collapsed. Also observed in all samples were nongerminated zoospore cysts (Figs. 6D and 7). The zoospore cyst depicted in Figure $6 \mathrm{D}$ appears to be only partially encysted because it is both (i) pleomorphic and (ii) retains a flagellum base. In addition, several zoospore cysts were noted of unusually small size (Fig. 7), the smallest of which measured $\approx 3 \mu \mathrm{m}$ in diameter. Clusters of zoospore cysts were common (Fig. 7) but it is unknown whether these clusters maintained their integrity as they engaged the filter membranes. An amorphous matrix was often observed adhered to both zoospore cysts and germ tubes (Figs. 6 and 7) and was interpreted as precipitates from the nutrient solution. However, fungal and plant secretions could not be ruled out. In addition, a presumptive cell secretion was periodically observed between clustered zoospore cysts (Fig. 7) and was interpreted to be of zoospore origin. The SEM assays were conducted three times and all stages described above were observed in all three zoosporeinfested Polymate filters assayed. In addition, none of the structures described in Figures 6 and 7 were observed in filters recovered from noninfested NFT systems.

\section{DISCUSSION}

Four cross-flow filter brands were evaluated for their efficiencies in reducing the numbers of suspended zoospore cysts in recirculating nutrient solutions. In plant bioassays, Honeycomb and Polymate filters yielded similar results over the course of the 28-day tests, and the percentages of plants exhibiting root rot and plant wilt were analogous among similarly rated filters (Tables 1 and 2). However, the Polymate 1- and 5- $\mu \mathrm{m}$-rated filters were ineffective in preventing plant disease when used as single filters, even though the first NFT tests (Fig. 4) suggested that these filters were removing $100 \%$ of the zoospore cysts. It was hypothesized that the 1- and 5- $\mu \mathrm{m}$ Polymate filters would have effectively removed all zoospore cysts and prevented plant disease because encysted zoospores of $P$. myriotylum are, on average, 8 to $10 \mu \mathrm{m}$ in diameter. This hypothesis was not confirmed. It was concluded that infective propagules of $P$. myriotylum were passing through the 1- and 5- $\mu \mathrm{m}$ Polymate filter membranes. The possibility that root and shoot symptoms were caused by cross-contamination of NFT units by $P$. myriotylum was rejected because of the negative results in the shore-fly and excised-healthy-root assays. Only one cross-contamination event was observed in over 5 years of research, and this data was deleted from the analyses.

Failure of single filters at presumptively effective pore ratings has been described in the literature. For example, when filtering J2 larvae of Globodera rostochiensis, Pratylenchus crenatus, and Meloidogyne incognita from hydroponic nutrient solutions, $100 \%$ successful removal of larvae occurred only when nominal ratings of filters were 1 to $3 \mu \mathrm{m}$, even though $\mathrm{J} 2$ larvae are generally 15 to $20 \mu \mathrm{m}$ in diameter by 250 to $300 \mu \mathrm{m}$ long (20). Failure of filters is also a common problem in the pharmaceutical industry, in which bacteria that measure up to $1.5 \mu \mathrm{m}$ long by $0.75 \mu \mathrm{m}$ wide are only effectively removed by filters nominally rated at 0.1 to $0.22 \mu \mathrm{m}$ (32). In a third example, Hong et al. (15) recently reported that motile zoospores of Pythium and Phytophthora spp. passed through thin-membrane filters with nominal pore sizes of

TABLE 3. Filter efficiency of seven double-filter combinations in nutrient film technique systems infested with zoospore cysts of Pythium myriotylum ${ }^{\mathrm{y}}$

\begin{tabular}{|c|c|c|c|c|c|}
\hline Filter $^{\mathrm{Z}}$ & $\begin{array}{c}\text { Zoospore cysts in tank } \\
\text { (no./liter) }\end{array}$ & $\begin{array}{l}\text { Zoospore cysts after } \\
\text { first filter (no./liter) }\end{array}$ & $\begin{array}{l}\text { Efficiency of } \\
\text { first filter }(\%)\end{array}$ & $\begin{array}{l}\text { Zoospore cysts after } \\
\text { second filter (no./liter) }\end{array}$ & $\begin{array}{c}\text { Efficiency of } \\
\text { second filter }(\%)\end{array}$ \\
\hline Poly-K (1.0) + Poly-K (1.0) & $182,222 \mathrm{a}$ & $522 \mathrm{ab}$ & $99.7 \mathrm{bc}$ & $341 \mathrm{a}$ & $55.3 \mathrm{c}$ \\
\hline Poly-O (1.0) + Poly-O (1.0) & $197,222 \mathrm{a}$ & $279 \mathrm{c}$ & $99.9 \mathrm{a}$ & $131 \mathrm{~b}$ & $56.6 \mathrm{c}$ \\
\hline Poly-K (1.0) + Poly-K (0.5) & $192,778 \mathrm{a}$ & $447 \mathrm{bc}$ & $99.8 \mathrm{abc}$ & $29 \mathrm{bc}$ & $93.6 \mathrm{~b}$ \\
\hline Poly-O (1.0) + Poly-O (0.5) & $196,111 \mathrm{a}$ & $400 \mathrm{bc}$ & $99.8 \mathrm{abc}$ & $14 \mathrm{bc}$ & $97.3 \mathrm{ab}$ \\
\hline Poly-K (1.0) + Abso-K (4.5) & $195,000 \mathrm{a}$ & $714 \mathrm{a}$ & $99.6 \mathrm{c}$ & $21 \mathrm{bc}$ & $97.6 \mathrm{ab}$ \\
\hline Poly-K (1.0) + Abso-K (1.2) & $225,556 \mathrm{a}$ & 396 bc & $99.8 \mathrm{ab}$ & $3 \mathrm{c}$ & $99.3 \mathrm{a}$ \\
\hline Poly-O (1.0) + Abso-O (4.5) & $197,222 \mathrm{a}$ & $591 \mathrm{ab}$ & $99.7 \mathrm{bc}$ & $17 \mathrm{bc}$ & $97.5 \mathrm{ab}$ \\
\hline
\end{tabular}

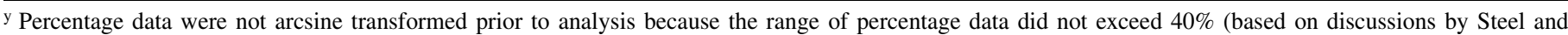

Torrie, 1980). Treatments in columns followed by the same letter were not significantly different based on analysis of variance and protected Fisher's leastsignificant difference test $(P \leq 0.05, n=9)$.

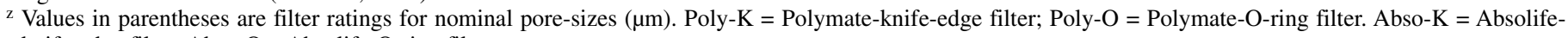
knife-edge filter; Abso-O = Absolife-O-ring filter.

TABLE 4. Effects of using two-stage Polymate filters to suppress disease development in peppers caused by Pythium myriotylum ${ }^{\mathrm{y}}$

\begin{tabular}{|c|c|c|c|c|c|}
\hline Treatment $^{\mathrm{z}}$ & Shoot fresh wt. (g) & Root fresh wt. (g) & Root disease rating & Wilt (\%) & Root symptoms (\%) \\
\hline (-) Control & $113.0 \mathrm{a}$ & $46.9 \mathrm{a}$ & $0.0 \mathrm{c}$ & $0 \mathrm{c}$ & $0 \mathrm{c}$ \\
\hline Polymate filters $(1.0+0.5 \mu \mathrm{m})$ & $115.1 \mathrm{a}$ & $50.1 \mathrm{a}$ & $0.13 \mathrm{~b}$ & $2 b$ & $2 \mathrm{~b}$ \\
\hline (+) Control & $52.1 \mathrm{~b}$ & $17.6 \mathrm{~b}$ & $4.0 \mathrm{a}$ & $90 \mathrm{a}$ & $97 \mathrm{a}$ \\
\hline
\end{tabular}

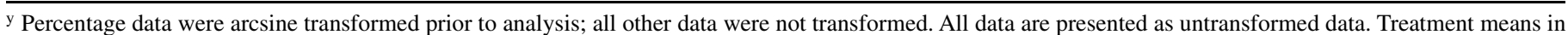
columns followed by similar letters were not significantly different based on analysis of variance and protected Fisher's least-significant difference tests $(P \leq$ $0.05, n=8)$.

${ }^{\mathrm{z}}$ Negative $(-)$ control $=$ no filters and noninoculated plants and positive $(+)$ control $=$ no filters but inoculated. 
$0.45 \mu \mathrm{m}$. In contrast to these article, Goldberg et al. (14) reported successful removal of zoospore cysts of Pythium aphanidermatum by a two-filter system composed of 20 - and 7- $\mu \mathrm{m}$ cross-flow filters. The 7- $\mu \mathrm{m}$ filter membrane used in the Goldberg et al. (14) study was notably thicker (16 mm thick) than the filter membranes used either in the literature cited above or in the current study ( $200 \mu \mathrm{m}$ to $2 \mathrm{~mm}$ thick). Thus, successful cross-flow filters may require both low nominal pore ratings $(\leq 5$ to $7 \mu \mathrm{m})$ and high membrane thickness to be successful.

Double- and triple-stage filter systems have generally demonstrated much greater success than single-stage filter units in the removal of infective propagules in hydroponic systems $(14,20)$ or dump-tank wash water (27). Thus, a series of double-filter assays were conducted with Polymate and Absolife filters (Table 3). The NFT systems were configured with two filter housings plumbed in series in which sample ports were available after both the first and second filters. Thus, each filtration step could be independently monitored. Results (Table 3 ) indicated that the first filters were $>99 \%$ efficient in removing zoospore cysts from nutrient streams but that the filter efficiencies for the second filters generally decreased and ranged between 55 and $<99 \%$ effective removal of cysts.

Why would the efficiencies of the second filters decrease? First, the largest reductions in efficiencies for the second filters were observed when identical filters were used in series. This result is consistent with the conclusion that the population of zoospore cysts that made it through the first filter was "pre- selected" to more efficiently make it through the second filter. A double-filter system with each filter being composed of the same brand of filter and rated at the same nominal pore size appears to be unable to adequately remove $100 \%$ of the suspended zoospore cysts. Second, when Polymate 1- $\mu$ m filters were used as a first stage in conjunction with Absolife filters of either $0.5,1.2$, or $4.5 \mu \mathrm{m}$ in pore ratings as the second stage, the efficiencies of the second filters improved but never reached $100 \%$. In addition, during the double-filter plant bioassay experiment (Table 4), Polymate filters rated at 1 and $0.5 \mu \mathrm{m}$ were used but root disease caused by $P$. myriotylum developed on peppers, albeit at very low levels. Thus, even with a diversity of double-filter configurations, the brands and pore sizes used in the current study failed to entrap $100 \%$ of zoospore cysts. Third, most cross-flow filters are given "nominal" pore-size ratings based on the efficiency of removing diatomaceous earth particles suspended in solution. Diatomaceous earth (Fig. 2B) is composed of jagged-edged, rigid particles that are likely entrapped relatively easily by the filter fibers (Fig. 2A). In contrast, the zoospore cysts of $P$. myriotylum are likely more pliable than rigid mineral particles. Thus, there are at least three possible reasons why double cross-flow filters were unable to remove $100 \%$ of zoospores cysts in hydroponic solutions: (i) pliable pleomorphic cysts were forced through filter membranes by the dynamic pressure exerted by the flow dynamics of the recirculating nutrient solutions, (ii) cysts passed through filters due to atypical small sizes, or (iii) blow-by defects in either the filter membrane or seals allowed some cysts to avoid the filter matrix entirely.
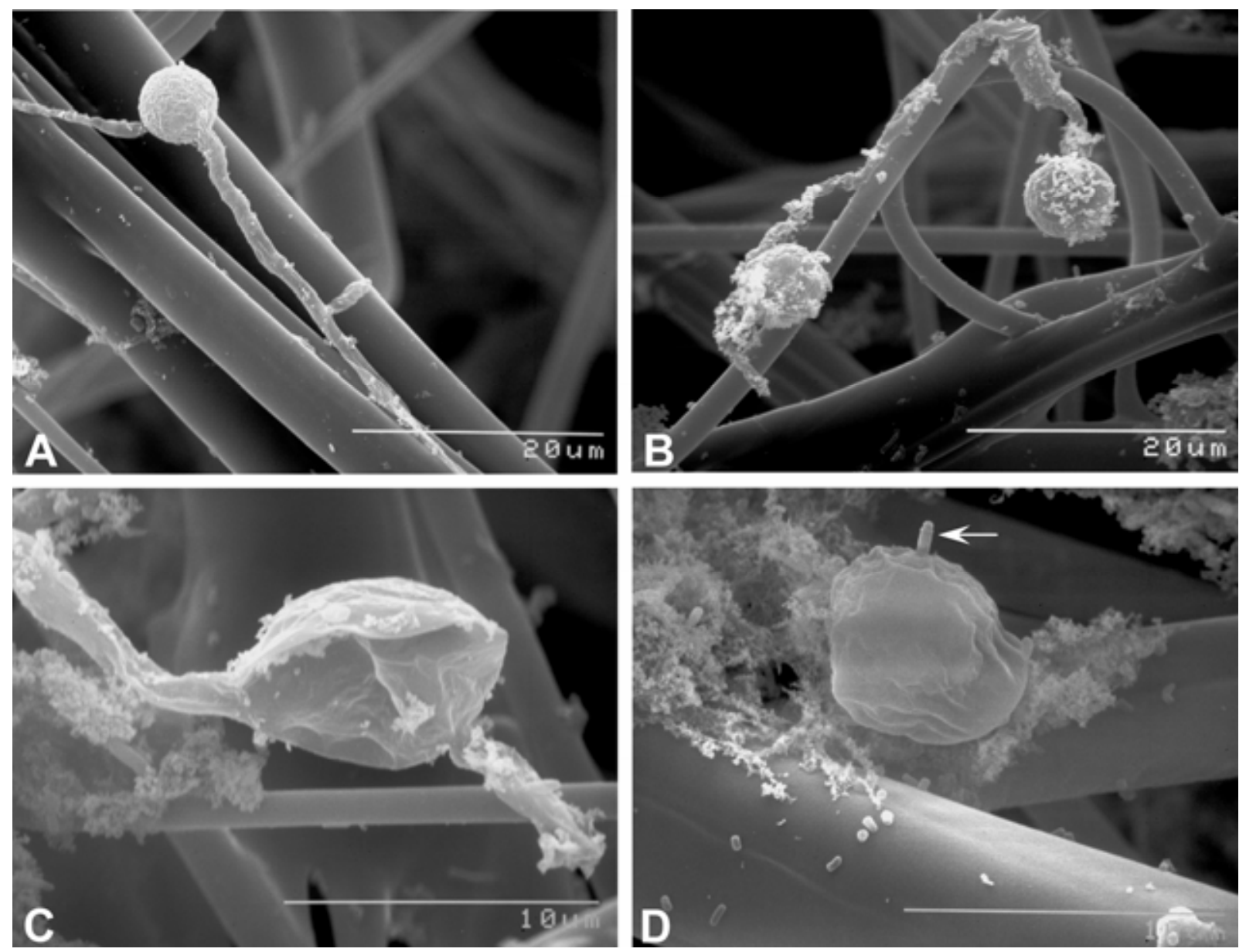

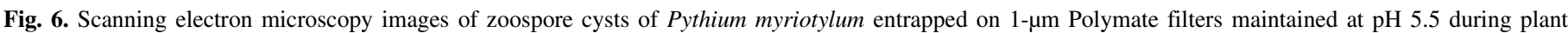

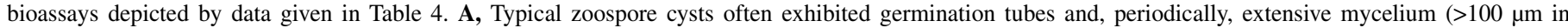

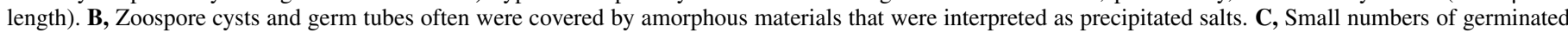

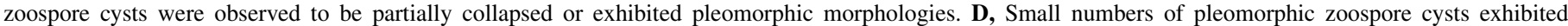

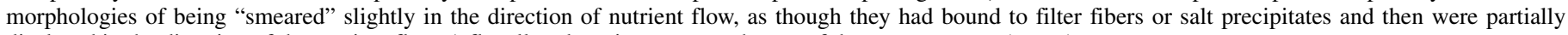
displaced in the direction of the nutrient flow. A flagellum base is present at the top of the zoospore cyst (arrow). 
Results of SEM imaging support the conclusion that some zoospore cysts of $P$. myriotylum in hydroponic nutrient solutions (i) may occur in unusually small, atypical sizes (2 to $3 \mu \mathrm{m}$ in diameter) or (ii) may retain pliable pleomorphic states of partial encystment. Both morphological states are likely to increase the zoospore penetration of filter membranes, leading to failure of filters rated at presumptively effective small pore sizes. One possible mechanism that would yield atypically small zoospore cysts is repetitional diplanetism (7), in which secondary motile zoospores are produced directly from encysted primary zoospores. When secondary sporangia and zoospores are produced through diplanetism, they are often significantly smaller in size than primary structures $(7,28)$. Results from the current study do not provide adequate resolution on whether the atypically small zoospore cysts were formed as small primary zoospores from normal sporangia (33) or through diplanetism (7); nonetheless, atypically small zoospore cysts were observed attached to filter membranes.

Although filter failure for pythiaceous species has been reported (15), no previous literature was found that provided a potential explanation. This report is the first to identify the possibility that membrane filters may have significant difficulties entrapping all infective propagules of at least some pythiaceous pathogens because of the occurrence of either atypically small zoospore cysts, pliable pleomorphic zoospore cysts, or both. In addition, repetitional diplanetism in pythiaceous species $(7,28)$ offers a third possible explanation for the failure of the cross-flow membrane filters tested here. However, use of thicker filter materials at small nominal ratings of at least $7 \mu \mathrm{m}$, as reported by Goldberg et al. (14), may enhance the removal of zoospore cysts and approach $100 \%$ effective filtration of infective propagules.

The research described herein was motivated by the successful report of filtration of pythiaceous fungi by Goldeberg et al. (14) and by several reports of successful filtration of other pathogens in hydroponic systems or wash water $(20,22,26,27)$. However, the specific filter brands and pore sizes chosen here were not completely effective in protecting pepper plants from infection by $P$. myriotylum. One caveat to this conclusion is the possibility that, at lower concentrations of zoospore cysts, plant disease caused by $P$. myriotylum might be suppressed through a complete cropping cycle (up to 120 days for peppers). High concentrations of zoospore cysts (150 to 200 cysts $/ \mathrm{ml}$ ) were used in the plant bioassays in order to test the filtration systems under "worst-case" scenarios for recirculating hydroponic systems. During the course

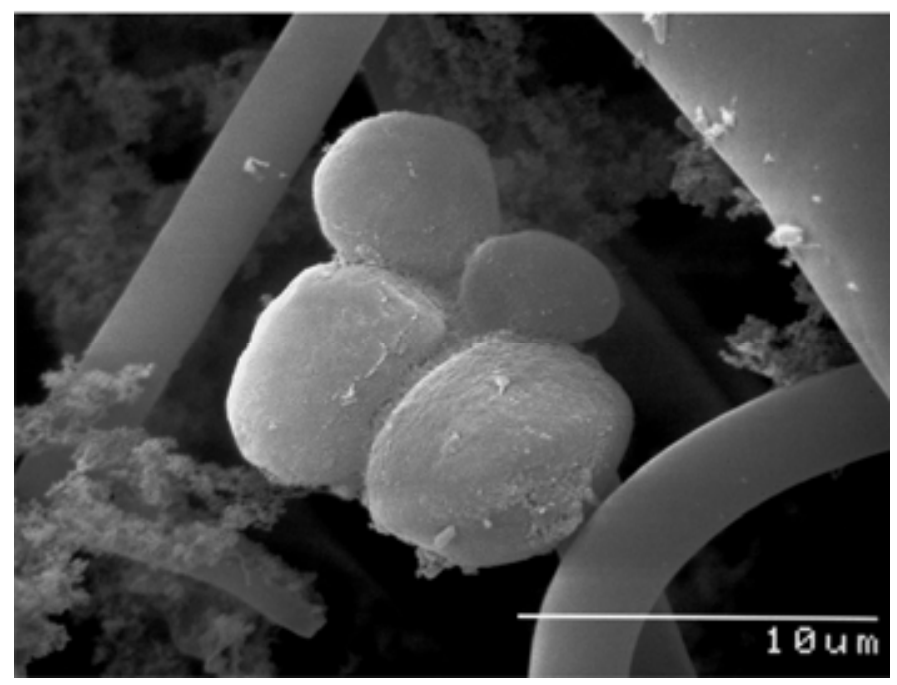

Fig. 7. Zoospore cysts of Pythium myriotylum were not constrained exclusively to the range of 8 to $10 \mu \mathrm{m}$ but periodically exhibited atypically small diameters. The smallest zoospore cyst depicted here measured $3 \mu \mathrm{m}$ in diameter. Clumps of zoospore cysts were rare but did occur. When observed, aggregates exhibited a cellular matrix between bound zoospore cysts. of the natural epiphytotics in the hydroponic systems monitored for this project, the numbers of infective propagules of $P$. myriotylum recovered from the recirculating nutrient solutions typically averaged 1 to $10 \mathrm{CFU} / \mathrm{ml}$ but, periodically, concentrations of 100 to 150 cysts $/ \mathrm{ml}$ were detected. Lower concentrations of zoospore cysts may have improved the prophylactic effects of the filters.

The results depicted in Table 3 do not agree with the results for Polymate and Absolife filters given in Figure 4. The first tests with single Polymate and Absolife filters (Fig. 4) used a zoospore assay procedure that had a detection limit of 1,000 zoospore cysts/liter but the assay procedure used in the double-filter tests (Table 3 ) had a detection limit of 2 zoospore cysts/liter. Thus, the results between Figure 4 and Table 3 are explicable based on the detection limits of the zoospore cyst assays (i.e., some zoospore cysts passed the Polymate filters in the single-filter tests [Fig. 4] but the numbers were below the detection limit of the "microdrop assay"). A high-volume zoospore cyst assay that filters 500 to $1,000 \mathrm{ml}$ of nutrient solution per sample onto a gridded filter membrane is recommended for future research on cross-flow filter efficiency in order to lower the detection limit of the zoospore cyst assay and, thus, more accurately measure the true efficiencies of the filters.

A successful filtration system for hydroponic nutrient solutions would likely require a more complex system than was tested here, using possibly ceramic filters, thicker polypropylene filters, or smaller pore-sized filters. However, even if an effective filtration system can be developed, there are significant questions about cost and longevity of filters that must be addressed. Typical hydroponic nutrient solutions are maintained near pH 6.5 (21) but, as was shown in the 56-day experiments in which bacterial populations and $\left[\mathrm{H}^{+}\right]$were monitored in hydroponic systems maintained at $\mathrm{pH} 4.5,5.5$, or 6.5 (Fig. 5), filters can clog easily if the $\left[\mathrm{H}^{+}\right]$is close to the precipitation point of the nutrient salts (typically, $>\mathrm{pH}$ 6.7). Although clogging of filter systems in recirculating hydroponic systems is a common problem $(18,20,22)$, filter clogging may be minimized by operating hydroponic systems at or below pH 5.5.

Several recommendations are suggested that may enhance the effectiveness of small to moderately sized filtration systems for control of pythiaceous pathogens in hydroponic systems. First, cross-flow filters should be at least $1 \mathrm{~cm}$ thick and rated at 5 to $7 \mu \mathrm{m}$ or lower. The thicker filter matrix should provide a greater path length through which atypically small or pliable pleomorphic zoospore cysts can be entrapped. Second, the $\left[\mathrm{H}^{+}\right]$of the recirculating nutrient solution should be maintained at $\mathrm{pH} 5.5$ or lower. Hydrogen ion concentrations at or above $\mathrm{pH} 6.5$ should be avoided in order to prevent the precipitation of nutrient salts. Third, at least two-stage filtration should be used in order to mitigate the inefficiencies of a single filter, as demonstrated here. In addition, two-stage filtration systems should not use similar pore sizes for both filters but, instead, should utilize pore ratings that extend to the smallest size possible given the constraints of the hydroponic system. Fourth, to increase the longevity of the filters, prefilter screens should be used to remove bulky root and leaf litter that can quickly clog the micron-scale primary filters. Fifth, shore flies and fungus gnats within greenhouses must be carefully monitored and controlled in order to prevent the transmission of ingested infective propagules among recirculating hydroponic systems (e.g., oospores) (13).

\section{ACKNOWLEDGMENTS}

We thank the Walt Disney World Company for their support of the research described herein; B. Norman, M. Serracin, and T. Blank for their technical assistance in building and monitoring the research equipment; and J. Marois and M. E. Stanghellini for editorial comments on the presubmitted manuscript. 


\section{LITERATURE CITED}

1. Bates , M. L., and Stanghellini, M. E. 1984. Root rot of hydroponically grown spinach caused by Pythium aphanidermatum and P. dissotocum. Plant Dis. 68:989-991.

2. Berkelmann, B., Wohanka, W., and Krczal, G. 1995. Transmission of pelargonium flower break virus (PFBV) by recirculating nutrient solutions with and without slow sand filtration. Acta Hortic. 382:256-262.

3. Brand, T., and Alsanius, B. W. 2004. Cell-wall degrading enzymes in slow sand filters of closed hydroponic systems. J. Hortic. Sci. Biotechnol. 79:228-233.

4. Calvo-Bado, L. A., Pettitt, T. R., Parsons, N., Petch, G. M., Morgan, J. A. W., and Whipps, J. M. 2003. Spatial and temporal analysis of the microbial community in slow sand filters used for treating horticultural irrigation water. Appl. Environ. Microbiol. 69:2116-2125.

5. Deniel, F., Rey, P., Cherif, M., Guillou, A., and Tirilly, Y. 2008. Indigenous bacteria with antagonistic and plant-growth-promoting activities improve slow-filtration efficiency in soilless cultivation. Can. J. Microbiol. 50:499-508.

6. Dhingra, O. D., and Sinclair, J. B. 1985. Basic Plant Pathology Methods. CRC Press, Inc., Boca Raton, FL.

7. Drechsler, C., 1930. Repetitional diplanetism in the genus Phytophthora. J. Agric. Res. 40:557-573.

8. Ehret, D. L., Alsanius, B., Wohanka, W., Menzies, J. G., and Utkhede, R. 2001. Disinfection of recirculating nutrient solutions in greenhouse horticulture. Agronomie 21:323-339.

9. Evans, S. G. 1979. Susceptibility of plants to fungal pathogens when grown by the nutrient-film technique (NFT). Plant Pathol. 28:45-48.

10. Funck-Jensen, D., and Hockenhull, J. 1983. The influence of some factors in the severity of Pythium root rot of lettuce in soilless (hydroponic) growing systems. Acta Hortic. 133:129-136.

11. Garibaldi, A., Minuto, A., Grasso, V., and Gullino, M. L. 2003. Application of selected antagonistic strains against Phytophthora cryptogea on gerbera in closed soilless systems with disinfection by slow sand filtration. Crop Prot. 22:1053-1061.

12. Gold, S. E., and Stanghellini, M. E. 1985. Effects of temperature on Pythium root rot of spinach grown under hydroponic conditions. Phytopathology 75:333-337.

13. Goldberg, N. P., and Stanghellini, M. E. 1990. Ingestion-egestion and aerial transmission of Pythium aphanidermatum by shore flies (Ephydrinae: Scatella stagnalis). Phytopathology 80:1244-1246.

14. Goldberg, N. P., Stanghellini, M. E., and Rasmussen, S. L. 1992. Filtration as method for controlling Pythium root rot of hydroponically grown cucumbers. Plant Dis. 76:777-779.

15. Hong, C., Richardson, P. A., and Kong, P. 2002. Comparison of membrane filters as a tool for isolating pythiaceous species from irrigated water. Phytopathology 92:610-616.

16. Kannwischer, E., and Mitchell, D. J. 1978. The influence of a fungicide on the epidemiology of tobacco black shank of tobacco. Phytopathology 68:1760-1765.
17. Kennedy, R., and Pegg, G. F. 1989. The effect of root zone temperature on the control of Phytophthora cryptogea in rockwool-grown tomato plants. Acta Hortic. 238:165-171.

18. Liu, M., Lau, A. K., and Lo, K. V. 1999. Ultrafiltration tests for the reutilization of greenhouse wastewater. J. Environ. Sci. Health B34:1101-1110.

19. McKinnon, B. T., and Avis, K. E. 1993. Membrane filtration of pharmaceutical solutions. Am. J. Hosp. Pharm. 50:1921-1936.

20. Moens, M., and Hendrickx, G. 1992. Drainwater filtration for the control of nematodes in hydroponic-type systems. Crop Prot. 11:69-73.

21. Nelson, P. V. 1978. Greenhouse Operation \& Management. Reston Publishing Company, Inc., Reston, VA.

22. Ohtani, T., Kaneko, A., Fukuda, N., Hagiwara, S., and Sase, S. 2000. Development of a membrane disinfection system for closed hydroponics in a greenhouse. J. Agric. Engang. Res. 77:227-232.

23. Paulitz, T. C., and Belanger, R. R. 2001. Biological control in greenhouse systems. Annu. Rev. Phytopathol. 39:103-133.

24. Rey, P., Benhamou, N., and Tirilly, Y. 1998. Ultrastructural and cytochemical investigation of asymptomatic infection by Pythium spp. Phytopathology 88:234-244.

25. Schuerger, A. C., and Mitchell, D. J. 1992. Effects of temperature and hydrogen ion concentration of attachment of macroconidia of Fusarium solani $\mathrm{f}$. sp. phaseoli to mung bean roots in hydroponic nutrient solution. Phytopathology 82:1311-1319.

26. Sholberg, P. L., and Owen, G. R. 1990. Populations of propagules of Penicillium spp. during immersion dumping of apples. Can. Plant Dis. Surv. 70:11-14.

27. Spotts, R. A., and Cervantes, L. A. 1993. Use of filtration for removal of conidia of Penicillium expansum from water in pome fruit packinghouses. Plant Dis. 77:828-830.

28. Stanghellini, M. E., and Hancock, J. G. 1971. The sporangium of Pythium ultimum as a survival structure in soil. Phytopathology 61:157-164.

29. Stanghellini, M. E., and Kronland, W. C. 1986. Yield loss in hydroponically grown lettuce attributed to subclinical infection of feeder rootlets by Pythium dissotocum. Plant Dis. 70:1053-1056.

30. Stanghellini, M. E., and Rasmussen, S. L. 1994. Hydroponics: A solution for zoosporic pathogens. Plant Dis. 78:1129-1138.

31. Steel, R. G. D., and Torrie, J. H. 1980. Principles and Procedures of Statistics: A Biometrical Approach. McGraw-Hill Book Company, New York.

32. Sundaram, S., Auriemma, M., Howard, G., Jr., Brandwein, H., and Leo, F. 1998. Application of membrane filtration for removal of diminutive bioburden organisms in pharmaceutical products and processes. J. Pharm. Sci. Technol. 53:186-201.

33. Van Der Plaats-Niterink, A. J. 1981. Monograph of the Genus Pythium. Studi. Mycol. Monogr. Ser. 21:1-242.

34. van Voorst, G., van Os, E. A., and Zadoks, J. C. 1987. Dispersal of Phytophthora nicotiannae on tomatoes grown by nutrient film technique in a greenhouse. Neth. J. Plant Pathol. 93:195-199.

35. Wohanka, W. 1995. Disinfection of recirculating nutrient solutions by slow sand filtration. Acta Hortic. 382:246-255. 